\title{
Nasopharyngeal and laryngeal amyloidosis: a case report
}

\author{
Nazofarenks ve larenks amiloidozisi: Bir olgu sunumu \\ Veysel Yurttaş', Kazım Bozdemir'2, Behçet Tarlak², Aylin Yazgan ${ }^{3}$ \\ ${ }^{\prime}$ Department of Otorbinolaryngology, Faculty of Medicine, Abant Izzet Baysal University, Bohu, Turkey \\ ${ }^{2}$ Department of Otorbinolaryngology, Ankara Atatiirk Training and Research Hospital, Ankara, Turkey \\ ${ }^{3}$ Department of Pathology, Ankara Atatiirk Training and Research Hospital, Ankara, Turkey
}

\begin{abstract}
A 49-year-old woman admitted to our clinic due to a progressive hoarse voice for 4 years, foreign body sensation in the back of her throat, otalgia, hoarseness and mouth breathing. Nasolaryngoscopy demonstrated a right nasopharyngeal mass extending to oropharynx. Indirect laryngoscopy revealed a granulomatous lesion originating from right band ventricle and extending on the right vocal fold. The granulomatous lesion did not alter correct laryngeal mobility. There was no history of difficulty in swallowing. A contrast enhanced computed tomography showed a smooth mass involving nasopharynx and glottis. A direct laryngoscopy was planned for excisional biopsy of the lesion. Histopathological examination revealed nasopharyngeal and laryngeal amyloidosis. Further evaluations were negative for systemic amyloidosis. The aim of the report is to present an extremely rare case of isolated primary nasopharyngeal and laryngeal amyloidosis and discuss by using current literature knowledge.
\end{abstract}

Keywords: Primary amyloidosis, nasopharynx, larynx.

Amyloidosis is a clinical disorder caused by extracellular proteinaceous deposits of insoluble abnormal group of fibrils with characteristic microscopic, histochemical, and ultrastructural features. Amyloid is an extracellular amorphous eosinophilic protein, which displays apple-green birefringence with polarized light when stained with Congo red or shows metachromasia with crystal violet or methyl violet dyes. ${ }^{[1-4]}$ Systemic and localized forms are the main clinical categories of the amyloidosis. Systemic amy-

\begin{abstract}
Özet
Kırk dokuz yaşındaki kadın hasta 4 yıldan beri ilerleyen kısık ses, boğazının arka tarafında yabancı cisim hissi, kulak ağrısı, ses kısıklı̆ğ ve ağızdan soluma yakınmalarıyla kliniğimize kabul edildi. Nazolarengoskopi orofarenkse doğru uzanan bir sağ nazofarengeal kitleyi göstermekteydi. İndirekt larengoskopi sağ ventrikül bandından kaynaklanan ve sağ vokal kordun üzerine doğru uzanan bir granülomatöz kitleyi ortaya çıardı. Granülomatöz kitle normal larenks mobilitesini bozmuyordu. Yutma zorluğu öyküsü yoktu. Kontrastlı bilgisayarlı tomografi nazofarenks ve glotisi tutan düzgün yüzeyli bir kitlenin var olduğunu gösterdi. Lezyonun eksizyonel biyopsisi için direkt larengoskopi planlandi. Histopatolojik inceleme nazofarenks ve larenks amiloidozunu ortaya çıkardı. İleri değerlendirmelerde sistemik amiloidoz saptanmadı. Bu olgu sunumunun amacı son derecede seyrek görülen izole primer nazofarenks ve larenks amiloidozu olgusunu sunmak ve güncel literatür bilgilerini kullanarak tartışmaktır.
\end{abstract}

Anahtar sözcükler: Primer amiloidoz, nazofarenks, larenks.

loidosis can manifest as immunoglobulin light chain derivative (AL) amyloidosis, which is associated with primary systemic amyloidosis, multiple myeloma, or plasma cell dyscrasias. Amyloid associated (AA) amyloid occurs in patients with chronic inflammatory conditions or neoplastic disease. Familial amyloidosis is a rare manifestation of systemic amyloidosis which accounts for less than $2 \%$ of the cases. ${ }^{[5]}$ In humans, more than 20 different, unrelated proteins are known to form amyloid fibrils.
Correspondence: Veysel Yurttaş, MD. Department of Otorhinolaryngology, Faculty of Medicine, Abant Izzet Baysal University, 14280, Bolu, Turkey.

e-mail: vyurttas@hotmail.com

Received: January 15, 2014; Accepted: February 22, 2014
Online available at: www.jmedupdates.org doi:10.2399/jmu.2014003008 QR code: 
Systemic amyloidosis can affect virtually any organ or tissue in the body. In localized type, the most common region of involvement is laryngotracheal system. ${ }^{[+]}$The most common site of involvement in head and neck region is larynx..$^{[4,6-8]}$ Amyloidosis constitutes approximately $1 \%$ of the all benign lesions of the larynx. ${ }^{[1,3,4,6,7,9]}$ Besides this, the diagnosis of amyloidosis affecting head and neck region is very rarely encountered due to its subclinical presentation. Nasopharyngeal amyloidosis is an extremely rare condition, and few cases have been reported in the literature so $\mathrm{far}^{\left[{ }^{[8]}\right.}$ In addition to this, there are no case reports regarding combined nasopharyngeal and laryngeal amyloidosis in the literature.

In this case report, we aimed to present a rare case of nasopharyngeal and laryngeal amyloidosis and to discuss the clinical presentation, diagnosis, and treatment options of this rare entity in the light of current knowledge.

\section{Case Report}

A 49-year-old female patient admitted to our clinic due to a hoarse voice for 4 years which progressed for the last 2 months with the complaints of foreign body sensation in the back of the throat, earache and mouth breathing. There was no history of difficulty in breathing, painful deglutition or swallowing. She had a history of smoking for the last 30 years. She had also chronic inactive hepatitis B virus infection. On otorhinolaryngologic examination, nasolaryngoscopy demonstrated a right nasopharyngeal mass extending into the oropharynx (Fig. 1a). Indirect laryngoscopy revealed a granulomatous lesion originating from the right ventricular band and extending onto the right vocal fold (Fig. 1b). The laryngeal motility was not affected by the granulomatous lesion. A contrast- enhanced computed tomography (CT) scan of the patient showed the presence of a smooth mass anterior to the right vocal cord and obliterating the fat plan of paraglottic region (Fig. 2). The mass was close to thyroid cartilage but it didn't invade thyroid or arytenoids cartilages. CT scan of the nasopharynx demonstrated an asymmetric smooth mass originating from the right nasopharyngeal wall and extending to the oropharyngeal level.

Direct laryngoscopy and biopsy were performed under general anesthesia. The laryngeal mass was removed by endoscopic curettage. Biopsy was taken from the nasopharyngeal mass, which was removed totally at the same time. Biopsy of the lesions demonstrated amyloidosis as a result of histopathological examination of specimens and immunohistochemical analysis demonstrated light chain restriction of the plasma cells (Kappa ( $\kappa)$ and lambda $(\lambda)$ antibodies).

Fig. 3 demonstrates the amyloid accumulation stained with hematoxylin-eosin and Congo red. Further evaluation of the case was made for the presence of systemic amyloidosis by nephrology clinic. Genetic screening of familial Mediterranean fever was negative. Ultrasonographic imaging of urinary tract and intravenous pyelography findings were all normal. Therefore, the case was considered to have primary localized amyloidosis of nasopharynx and larynx.

\section{Discussion}

There have been a variety of classifications of amyloidosis in terms of biochemical, clinical and precursor protein characteristics. Biochemically, amyloidosis is categorized into forms as type AL (immunoglobulin light chain derivative) and AA (amyloid associated ${ }^{[10]}$ Clinically, it is divid-
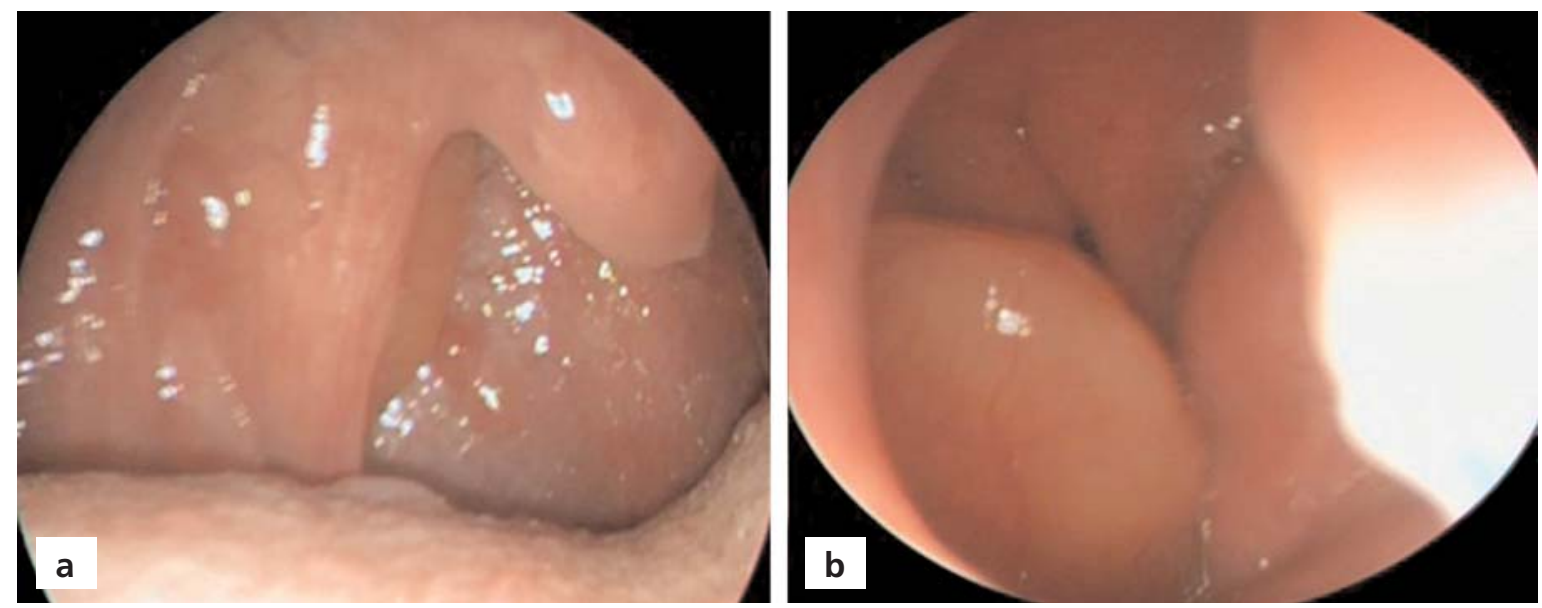

Fig. 1. Appearance of the amyloidosis lesion in nasopharynx (a) and larynx (b). 

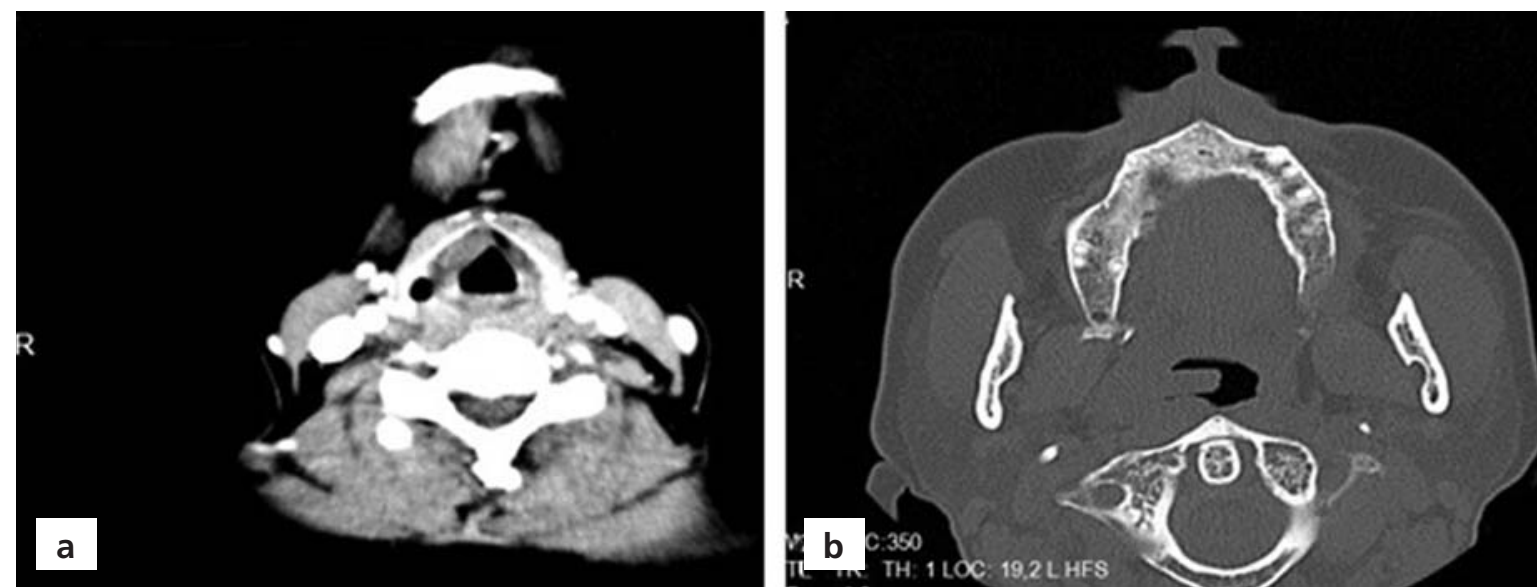

Fig. 2. Computed tomography. CT scans of larynx (a) and nasopharynx (b).

ed as systemic, localized, primary, secondary, familial, senile, hemodialysis-associated, and myeloma associated amyloidosis. ${ }^{[1,2,3,11]}$ The most common precursor proteins are $\mathrm{L}$ chains of the lambda class, which is twice as prevalent as kappa $\mathrm{L}$ chains.

The frequency of localized form is approximately $9 \%$ to $15 \%$ of all the cases of amyloidosis. Localized deposits of amyloid are found in the head and neck, aerodigestive system, and lower respiratory tract in the absence of systemic involvement or other associated disease. ${ }^{[10]}$ The most common sites of involvement in the head and neck are larynx, subglottis and thyroid. ${ }^{[4,6-8]}$ Other sites include the orbit, salivary glands, paranasal sinuses, and oral cavity. The larynx, especially ventricles, true and false vocal cords are the most common sites of involvement in the respiratory tract for localized amyloidosis. ${ }^{[12]}$ Laryngeal amyloidosis is generally localized and it is not associated with systemic disease. ${ }^{[10]}$ Nasopharyngeal amyloidosis is extremely rare. In the present case, coincidental involvement of nasopharyngeal and laryngeal structures was reported.

Laryngeal amyloidosis is a slowly progressive disease with unknown etiology. ${ }^{[3,9]}$ It can cause hoarseness, hemoptysis, chronic cough, voice changes, recurrent respiratory infections, and dysphagic symptoms according to size and location of the lesion. In the present case, patient's complaints were hoarse voice, foreign body sensation in the back of the throat, earache, and mouth breathing due to both nasopharyngeal and laryngeal involvement.
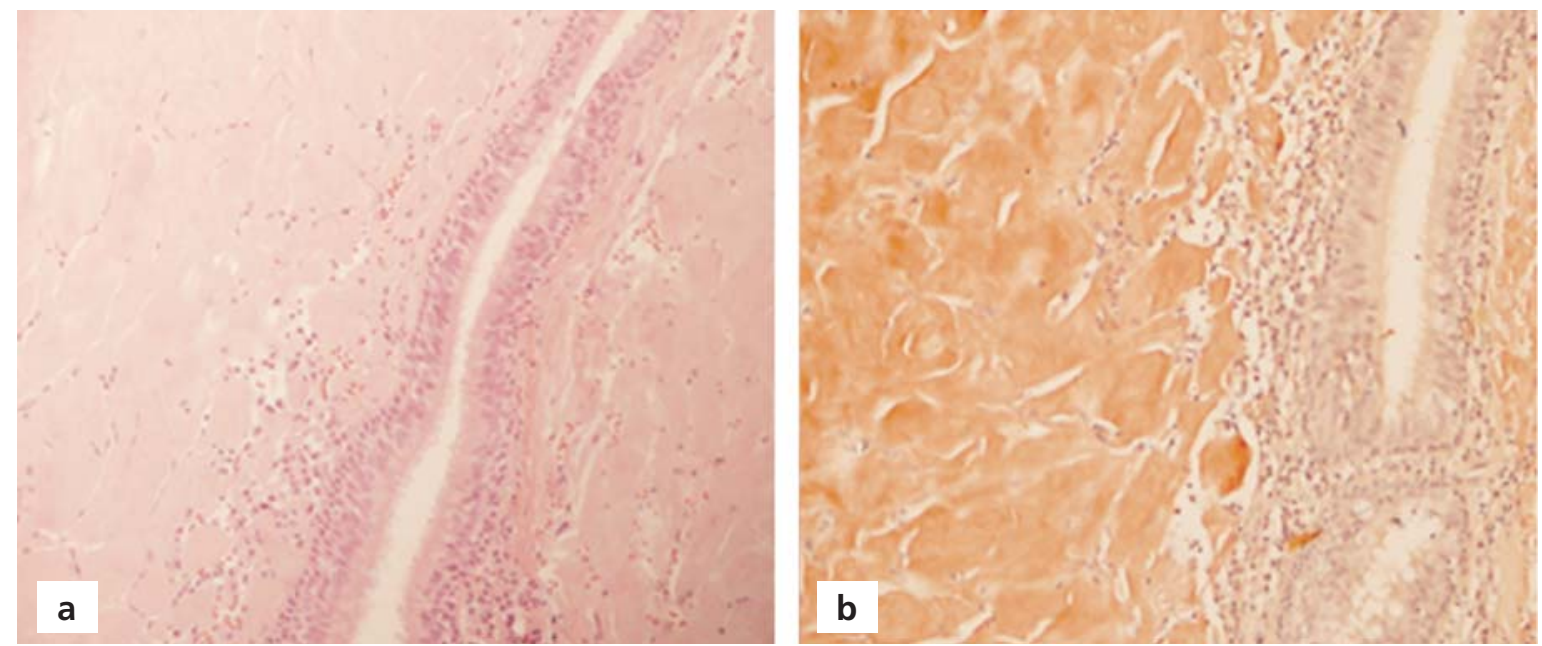

Fig. 3. Histopathological examination revealed an amorphous, acellular and eosinophilic amyloid deposition in the subepitelial region. Hematoxylin and eosin (a), and Congo red (b), (x20). 
Endoscopically, its appearance has been described as a yellowish, whitish or reddish polypoid mass. Macroscopically, it looks like a malignancy. The "gold standard" for the diagnosis of amyloid requires a tissue biopsy demonstrating characteristic changes in hematoxylin-eosin staining, and Congo red birefringence or metachromatic pink-violet staining with methyl violet or crystal violet. ${ }^{[8]} \mathrm{In}$ our case, examination of the tissue specimen using Congo red stain under polarized light revealed apple green birefringence which is characteristic for amyloidosis.

Larynx amyloidosis is generally in AL type. In a study, it was reported that more than $60 \%$ of the laryngeal deposits displayed a lambda light chain staining pattern, and $25 \%$ of them immunohistochemically showed a kappa pattern. ${ }^{[3]}$ In our patient, the amyloid deposits demonstrated lambda and kappa light chain restriction. Amyloid may be associated with multifocal and/or systemic disease. Clinical and laboratory (liver function tests, complete blood count, renal functional tests, etc.), radiological (chest X-ray, skeletal survey), cardiac, urinary and gastrointestinal tract evaluations were made to exclude any systemic diseases. After exclusion systemic diseases the diagnosis of localized amyloidosis was established.

For the treatment of localized amyloidosis of the larynx and nasopharynx, endoscopic surgical resection is usually preferred. ${ }^{[13]}$ Better surgical results were reported using $\mathrm{CO}_{2}$ laser. ${ }^{[4,6-8]}$ Adjuvant therapies such as irradiation, chemotherapy, and steroids have no proven benefit in the treatment of amyloidosis. ${ }^{\left[{ }^{6}\right.}$ In large lesions, laryngofissure, supraglottic laryngectomy or total laryngectomy may be required. ${ }^{[14]}$ Spontaneous regression of amyloidosis of larynx has been also reported.$^{[15]}$ Regular follow-up with periodic laryngeal and nasopharyngeal examination and imaging studies is required to detect recurrence at an early stage. Endoscopic surgical total removal of laryngeal and nasopharyngeal amyloidosis of our patient was performed under general anesthesia.

In conclusion, although it is rarely seen, amyloidosis should be considered in the differential diagnosis of nasopharyngeal and laryngeal masses. Clinical findings at nasopharyngoscopy and laryngoscopy are nonspecific, variable, and difficult to distinguish clinically from other lesions. The diagnosis is based on the histopathological examination of tissue samples. Surgical excision of the mass to prevent laryngeal and nasopharyngeal airway obstruction remains the treatment of choice.

Conflict of Interest: No conflicts declared.

\section{References}

1. Glenner GG. Amyloid deposits and amyloidosis. The beta-fibrilloses (first of two parts). N Engl J Med 1980;302:1283-92.

2. Grogan TM, Spier CM. The B cell immunoproliferative disorders, including multiple myeloma and amyloidosis. In: Knowles D, editor. Neoplastic hematopathology. Philadelphia: W.B. Saunders Co.; 1992. p. 1235-60.

3. Lewis JE, Olsen KD, Kurtin PJ, Kyle RA. Laryngeal amyloidosis: a clinicopathologic and immunohistochemical review. Otolaryngol Head Neck Surg 1992;106:372-7.

4. O'Halloran LR, Lusk RP. Amyloidosis of the larynx in a child. Ann Otol Rhinol Laryngol 1994;103:590-4.

5. Domínguez S, Wienberg P, Clarós P, Clarós A, Vila J. Primary localized nasopharyngeal amyloidosis. A case report. Int J Pediatr Otorhinolaryngol 1996;36:61-7.

6. Thompson LD, Derringer GA, Wenig BM. Amyloidosis of the larynx: a clinicopathologic study of 11 cases. Mod Pathol 2000;13:528-35.

7. Alaani A, Warfield AT, Pracy JP. Management of laryngeal amyloidosis. J Laryngol Otol 2004;118:279-83.

8. Pribitkin E, Friedman O, O'Hara B, Cunnane MF, Levi D, Rosen M. Amyloidosis of the upper aerodigestive tract. Laryngoscope 2003;113:2095-101.

9. Oğuz H, Safak MA, Demirci M, Arslan N. Familial primary localized laryngeal amyloidosis in two sisters. Kulak Burun Bogaz Ihtis Derg 2007;17:283-6.

10. Rodriguez-Romero R, Vargas-Serrano B, Cortina-Moreno B, Fernandez-Gallardo JM, Cervera-Rodilla JL. Calcified amyloidoma of the larynx. Am J Neuroradiol 1996;17:1491-3.

11. Godbersen GS, Leh JF, Hansmann ML, Rudert R, Linke RP. Organ-limited laryngeal amyloid deposits: clinical, morphological, and immunohistochemical results of five cases. Ann Otol Rhinol Laryngol 1992;101:770-5.

12. Green KM, Morris DP, Pitt M, Small M. Amyloidosis of Waldeyer's ring and larynx. J Laryngol Otol 2000;114:296-8.

13. Mitrani M, Biller HF. Laryngeal amyloidosis. Laryngoscope 1985;95:1346-7.

14. Aydin O, Ustundag E, Iseri M, Ozkarakas H, Oguz A. Laryngeal amyloidosis with laryngocele. J Laryngol Otol 1999;113:361-3.

15. Basut O, Coşkun H, Erişen L, Tezel İ, Onart S. Bir larengeal amiloidozis olgusu. Türk Otolarengoloji Arşivi 2003;41:164-8.

This is an open access article distributed under the terms of the Creative Commons Attribution-NonCommercial-NoDerivs 3.0 Unported (CC BYNC-ND3.0) Licence (http://creativecommons.org/licenses/by-nc-nd/3.0/) which permits unrestricted noncommercial use, distribution, and reproduction in any medium, provided the original work is properly cited.

Please cite this article as: Yurttaş V, Bozdemir K, Tarlak B, Yazgan A. Nasopharyngeal and laryngeal amyloidosis: a case report. J Med Updates 2014;4(3):130-133. 